\title{
Pragmatic effects of polarity items revealing focal prominence in Mandarin word order
}

\author{
I-Hsuan Chen
}

\author{
Correspondence: \\ ihsuanchen@berkeley.edu \\ University of California, Berkeley, \\ Berkeley, USA
}

\begin{abstract}
This paper investigates the information structure of Mandarin Chinese word order through studying the distribution of minimizers, a distinct class of negative polarity items. The emphatic nature of minimizers is an effective indicator for distinguishing the strength of focal prominence in different syntactic construals. The corpus analysis compares the frequency of minimizers in different word order patterns, in different strategies of modification, and in different forms. The results show that their distribution is associated with how arguments are profiled in the information structure since minimizers tend to occur in the positions where their pragmatic inferences are maximally induced. The distribution of minimizers is the result of weighing syntactic constraints and pragmatic effects. The study contributes to characterizing the fine differences of the word order patterns in terms of focal saliency.
\end{abstract}

\section{Background}

This study investigates the information structure of Mandarin word order through a close examination of the distribution of polarity expressions. Numeral phrases denoting a small quantity are widely employed as pragmatic reinforcers in Modern Mandarin. The pragmatic reinforcers concerned in this paper are negative polarity items (NPIs) in the form of 'one'-unit word ${ }^{1}$-noun, as shown in (1). ${ }^{2}$

(1) 不浪費一粒糧食

$$
\text { bú_làngfèi_[yí_lì_liángshí] }
$$

(They) did not waste a bit of food.

The type of NPIs falls in the category of minimizers. Minimizers, expressions designating a minimal amount or referring to an end point of a scale, are frequently employed for emphatic functions (Fauconnier 1975; Haspelmath 1997; Horn 1989; Israel 2011). They are found crosslinguistically, such as English lift a finger, sleep a wink, hurt a fly, and worth a red cent. They anchor the end point of a conceptual scale and evoke scalar inferences for emphatic function (Israel 2011). They form a distinctive class due to their narrow licensing conditions in that they appear in antiveridical

(c) The Author(s). 2017 Open Access This article is distributed under the terms of the Creative Commons Attribution 4.0 International License (http://creativecommons.org/licenses/by/4.0/), which permits unrestricted use, distribution, and reproduction in any medium provided you give appropriate credit to the original author(s) and the source, provide a link to the Creative Commons license, and indicate if changes were made. 
or antimorphic contexts (Giannakidou 2011). However, they are not equally employed in all kinds of nonveridical environments; they tend to appear in negative environments, as in (2).

(2) a. He did not lift a finger to help.

b. "He lifted a finger to help.

The discussion begins with the puzzle of the synchronic distribution of Mandarin 'one'phrases as minimizers. Modern Mandarin unmarked word order is VO (Verb Object) (Li and Thompson 1981), while OV (Object Verb) specifically profiles the preverbal object (Zhang 2000). The 'one'-phrases as minimizers can appear in both word order patterns, as in (3) and (4).

（3） 整場會議,他沒說一個字 ${ }^{3}$

zhěng_chăng_huìỳ,_tā__méi_shuō_[yí_ge_zì]

whole_CLF_conference_he_NEG_say_one_CLF_word

During the whole conference, he didn't say a word.

（4）整場會議,他一個字都/也沒說

zhěng_chăng_huìyì,_tā__yí_ge_zì]_dōu/yě_méi_shuō

whole_CLF_conference_he_one_CLF_word_FOC/FOC_NEG_say

During the whole conference, he didn't say even a word.

VO is dominant in Modern Mandarin, and hence, the typical position for minimizers as a grammatical object is expected to be postverbal. However, when they appear with a particular type of negation, they tend to appear in OV. This asymmetrical distribution can provide an answer to how arguments are profiled in different word order patterns with different syntactic constraints. Since minimizers are associated with the issues of negation, focus, and scalar inferences, the distribution of minimizers contributes to revealing the semantic and pragmatic properties encoded in a variety of syntactic constructions. Since the same phrase can appear in various environments, the choice of the construction is bound with other semantic or pragmatic motivations. The following corpus analysis will focus on explaining the reasons behind the asymmetrical distribution.

This paper is organized as follows. Section 2 defines the types of negators which frequently co-occur with minimizers and then shows how different types of negation influence the distribution in VO and OV. Section 3 provides an overview of the synchronic distribution of 'one'-phrases as minimizers under non-existential negation in Modern Mandarin. The constraints in the distribution will be related to the information structure of word order. Section 4 shows the distribution of minimizers under existential negation and discusses how the constraints of modification reflect the principles of profiling arguments. Section 5 offers a comparison of two types of minimizers with different degrees of grammaticalization. Their differences are connected to the various strategies of achieving emphatic scalar inferences. Section 6 summarizes the influences of pragmatic effects on the choice of syntactic constructions, offering an explanation to the puzzle. 


\section{The frequent types of negators with minimizers}

The Modern Mandarin 'one'-phrase data have been collected from Chinese Gigaword $^{4}$ (Huang 2009). The combination of 'one'-phrases as minimizers and three kinds of negation are examined in two types of word order, OV and VO. The three kinds of negation are divided into two types based on their existentiality. The non-existential type includes the generic/stative negator 不 bù and the negator for negating the instantiation of an event 沒 méi, while the existential type involves the negative predicate 沒有 méiyóu 'there be not' (Li and Thompson 1981). The three negators cover different ranges of environments. 不 $B \dot{u}$ is the most general and neutral form of negator for simple denial of assertions and for refusal. As in (5) and in (6), 不 bù does not involve completion regardless of the time frame, past or present.

（5）他不聰明

tā_bù_cōngmíng

he_NEG_smart

He is not smart.

（6）他不讀書

tā_bù_dúshū

he_NEG_study

He does/did not study.

If instantiation of events is concerned, the negator is 沒 méi, as shown in (7), where 沒 méi negates the instantiation of the drinking event.

（7）他沒喝酒

tā_méi_hē_jiǔ

he_NEG_drink_wine

He didn't drink wine.

Another negator 沒(有) méi(yǒu) is used when the main verb of the sentence is 有 yǒu. 有 yǒu has a number of different meanings, including existential, possessive, perfective, presentational, and assertive (Cheng 鄭良偉 1978; Huang and James 1987; Tsai 蔡 维天 2004b). The major function of its negative counterpart 沒(有) méi(yǒu) concerned in this study is the negation of the existentiality. In (8), the negator 沒有 méiyǒu includes both negation and an existential verb. The existential verb 有 yǒu can be optional when 沒 méi appears.

\section{（8）沒(有)水了 \\ méi_(yǒu)_shuǐ_le \\ NEG.EXT_there be_water_sentence-final PTC}

There is no more water.

This section concerns the interaction between 'one'-phrases as minimizers and the two types of negation divided by existentiality: existential negative predicate 沒 有 méiyǒu and non-existential 不 bù and negator 沒 méi. Regarding syntactic 
positions, 不 bù and non-existential 沒 méi follow the subject and precede the verb, while existential negative predicate 沒有 méiyǒu follows the general form of Mandarin existential sentence as in (9) (cited from Huang and James 1987). As shown in (10), the existential predicate generally precedes the NP in position III to introduce the existence of that NP. The expression in position IV must be semantically related to the NP in position III. As in (10), position IV is filled by an expression of predication, which is a descriptive clause or phrase. Position I hosts a locative NP if there is any.

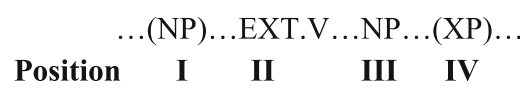

(10) 桌上有一本小說很有趣[Chinese Gigaword]

$\begin{array}{ll}\text { Position I } & \text { II III } \\ \text { zhuō__shàng_yǒu_[yì_běn_xiăoshuō]__hěn_yŏuqù } \\ \text { table_top_EXT.V__one__CL__novel_very_interesting } \\ \text { There is a novel on the table which is very interesting. }\end{array}$

Likewise, the negative predicate 沒有 méiyor $u$ generally precedes the NP in position III to introduce the existence of that NP, as in (11).

（11）屋內沒有一個人

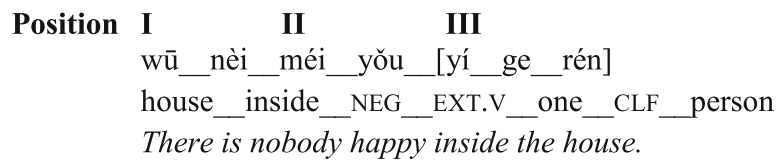

Due to the specific arrangement of the existential verb and the unaccusative subject in the Mandarin existential construction, the NP in the position of the unaccusative subject patterns like the object in the canonical VO. I follow Huang and James's (1987) analysis of Mandarin existential sentences and include yǒ NP/NP yǒu in this broader definition of $\mathrm{VO} / \mathrm{OV}$ construction due to the shared properties regarding the relative positions between the main predicate and the NP. The combination of an existential verb followed by a postverbal NP is labeled as VO. When the focus construction is involved, the NP whose existence is concerned precedes the existential predicate, as shown in (12). Analogously, the combination of a preverbal NP and the existential predicate is labeled as $\mathrm{OV}{ }^{5}$

（12）屋內一個人也沒有

wū_nèi_[yí_ge_rén]_yě_méi_yǒu

house_inside_one_CLF_person_FOC_NEG_EXT.V

There is not even a single person inside the house. 
The two word order patterns are defined for the purpose of comparing the influences of positional variation on the interpretation of minimizers under the scope of various negators. The positional variation is an effective indicator for distinguishing the strength of focal prominence of different syntactic constructions.

Since the two types of negation have great influences on the distribution of minimizers in word order, the following discussion begins with non-existential negators 不 bù and 沒 méi and continues to the existential negative predicate 沒有 méiyǒu.

\section{3 'One'-phrases as minimizers under non-existential negation}

For each of the non-existential negators 不 bù and 沒 méi, the two combinations of NEG-V... 'one' and 'one'...NEG-V are collected from the corpus. The former targets 'one'-phrases in VO, while the latter searches for 'one'-phrases in OV. The distribution of 'one'-phrases as minimizers in VO and OV is summarized in Fig. 1.

Notably, the overall number of 'one'-phrases as minimizers in OV outnumbers that in VO. The genres from Chinese Gigaword are restricted to newspaper and press releases, and therefore, the minimizers here are collected from written Chinese, which is stylistically formal. SVO is normally preferred in a formal register. Even given the restriction of genres, however, there are still more tokens in OV than in VO. The association between minimizers and OV in Modern Mandarin could be expected to be even more prominent in colloquial Mandarin.

The asymmetry of $\mathrm{VO}$ and $\mathrm{OV}$ in terms of accommodating 'one'-phrases as minimizers is reflected in how 'one'-phrases are interpreted in VO and OV. The 'one'-phrases with negator 不 bù or 沒 méi in VO have multiple functions, which can be divided based on their scalarity. The minimizer interpretation, as shown in (13)-(14), evokes scalar inferences. In (13), 'one'-phrases tend to be perceived as the smallest atomic units, which partly attributes to classifiers. The inclusion of a classifier in numeral phrases has become mandatory in Modern Mandarin. Classifiers overtly specify the basic unit of the object because they denote some prominently perceived or imputed properties of the entity to which associated nouns refer, as defined in Allan (1977). On the other hand, measure words can be contextually determined as minimal atomic units. For example, the measure word $\square$ kóu in (14) is understood as the smallest atomic unit in a drinking event. When 'one'-phrases are used as minimizers, they profile the minimal unit of a scale, which serves as the foundation for inducing scalar inferences. Since they refer to the minimal unit, the numeral 'one' cannot be replaced by other numerals.

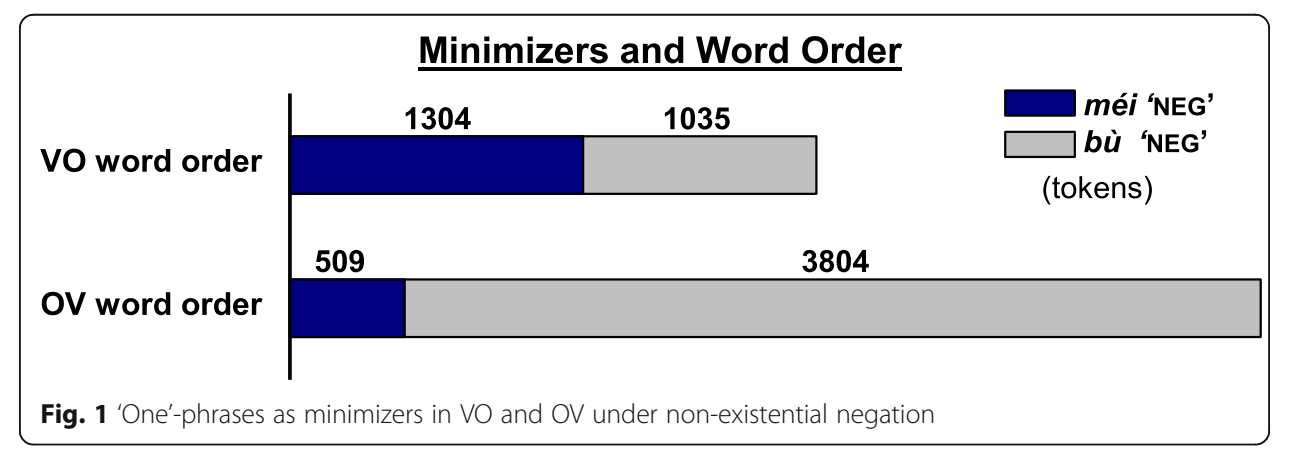


（13）沒流過一滴淚 [Chinese Gigaword]

méi_liú_guò_[yì_dì_lèi]

NEG_tear_ASP_one_drop_tear

hasn't even shed a tear

（14）不喝一口水 [Chinese Gigaword]

bù_hē_[yì_kǒu_shuǐ]

NEG_drink_one_MW(mouth)_water

did not drink even one mouthful of water

In $\mathrm{VO}$, 'one'-phrases under negation can have non-scalar interpretations. As in (15) and (16), the 'one'-phrases refer to an indefinite entity. The emphasis of indefiniteness instead of the precise quantity is reflected in the corresponding English translation "a NP". In this referential function, the numeral 'one' cannot be substituted with other numerals since 'one' does not contrast with other numerals.

（15）我們不需要一個獨立的國家 [Chinese Gigaword]

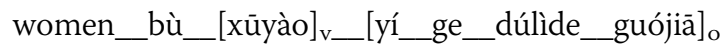

we_NEG_need_one_CLF_independent_country

We don't need an independent country.

（16）我不想成為一位政治領袖 [Chinese Gigaword]

wǒ_bù_[xiăng_chéngwéi] __[yí_wèi_zhèngzhì_lǐngxiù]

I_NEG_want_become_one_CLF_political_leader

I don't want to become a political leader.

The other non-scalar function of the 'one'-phrases under negation in $\mathrm{VO}$ is denoting a precise quantity, as in (17) and (18). In the two examples, the numeral 'one' can be used to contrast with other numerals, so the numeral 'one' can be replaced with other numerals.

（17）這類事情很可能不止一件 [Chinese Gigaword]

zhè_lèi_shìqíng_hěn_kěnéng_bù_zhì_[yí_jiàn]

this_kind_affair_very_likely_NEG_stop_one_CLF

It is likely that this is not the only one of this kind of affair.

（18）中國穩定不應繫於一人 [Chinese Gigaword]

zhōngguó_wěndìng_bù_yīng_xì_yú_[yì_rén]

China_stability_NEG_should_tie_at_one_person

The stability of China should not be tied to one person.

Departing from minimizers, the referential and quantity-denoting functions do not induce scalar inferences. These interpretations show that VO under negation can accommodate both scalar and non-scalar readings, and thus, a minimizer reading is not exclusive in VO.

In contrast, when 'one'-phrases appear with negation in OV, they are unambiguously understood as minimizer NPIs, as in (19) and (20). 
（19）波音公司不賣飛機,一架也不賣 [Chinese Gigaword]

pōyīn_gōngsī_bú_mài_fềijī__[yí_jià]_yě_bú_mài

Boeing_company_NEG_sell_airplane_one_CLF_FOC_NEG_sell

Boeing does not sell airplanes. It does not sell even one airplane.

（20）送了他四本書,他一本都沒看完 [Chinese Gigaword]

sòng_le_tā_sì_běn_shū,_tā_[yì_běn]_dōu_méi_kàn_wán

give_PRF_he_four_CLF_book_he_one_CLF_DOU_NEG_read_ASP

...gave him four books. He did not finish even one book.

No tokens from the corpus show that 'one'-phrases in the preverbal object position under negation are non-scalar. The preverbal position particularly favors the interpretation of minimizers due to its strong focal prominence; the preverbal position has been viewed as a focus construal since Old Chinese (Peyraube 1997a, 1997b) till Modern Mandarin (Tsai 蔡维天 2004a; Zhang 2000). The focus of the preverbal object position forces 'one'phrases to be interpreted as minimizers. The specific connection of the minimizer reading and $\mathrm{OV}$ is already attested in Old Chinese, but their marginal existence has not been discussed in the literature of Mandarin NPIs. The connection became statistically prominent in Early Mandarin Chinese when the negators were non-existential. This association has been shaped by the requirement of focal prominence for the emphatic nature of minimizers, leading to the synchronic distribution.

The minimizers with non-existential negation are associated with particular constructions in both $\mathrm{VO}$ and $\mathrm{OV}$ for emphatic purpose, resulting in the skewed distribution. They serve as effective diagnostics for focal prominence. Their property of attracting focal prominence will be examined in three constructions.

\subsection{Collocation with 任何 rènhé 'any' in VO and OV}

The distribution of minimizers in Modern Mandarin in Fig. 1 clearly illustrates the asymmetry of OV and VO in terms of securing a minimizer NPI reading. Since VO is open to multiple interpretations, additional mechanisms such as the occurrence of 任何 rènhé 'any' along with 'one'-phrases guarantee the minimizer reading. Mandarin 任何 rènhé exhibits both NPI and Free Choice Item (FCI) usages. The usage concerned in this study is the NPI one. In VO, when 任何 rènhé 'any' is added to a 'one'-phrase under negation, the 'one'-phrase must be understood as a minimizer, as shown in (21) and (22). Without 任何 rènhé 'any', the 'one'-phrases with negation in VO can emphasize indefinites or refer to a precise quantity, as shown in (15)-(18).

(21) 不放棄任何一次協商機會 [Chinese Gigaword] bú_fàngqì_rènhé_[yí_cì_xiéshāng_jīhuì]

NEG_give-up_any_one_CLF_negotiation_opportunity

did not give up any chance of negotiation

（22）去年沒買任何一本書 [Chinese Gigaword]

qùnián_méi_mǎi_rènhé__yì_běn_shū]

last-year_NEG_buy_any_one_CLF_book

last year did not buy any book 
It is noteworthy that both 任何 rènhé 'any' and minimizers are polarity items. Each of them can be used alone for inducing scalar readings by profiling an extreme value in an ordered set of alternatives, as shown in (23) and (24). When 任何 rènhe 'any' or the minimizer appear in VO, their associated NPs carry prosodic prominence or emphatic stress as an indication of receiving focal attention. Although the differences between the two types of polarity items are subtle in $\mathrm{VO}$, it is clear that the combination of two polarity items as in (22) has a stronger emphatic effect. Importantly, a 'one'-phrase in such a combination must be an NPI.

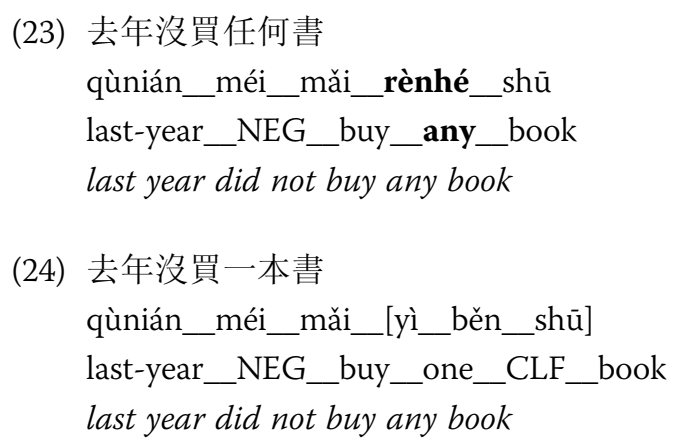

In contrast, the 'one'-phrases under negation in OV must be minimizers, and thus, the addition of 任何 rènhé 'any' does not contribute to specifying the scalar 'one'-phrases. Following this logic, there should be fewer cases of 任何 rènhé 'any' modifying 'one'-phrases in OV. As shown in Fig. 2, 任何 rènhé 'any' appears mostly in VO, while 任何 rènhé 'any' is barely found in OV.

The sharp contrast of the occurrences of 任何 rènhé 'any' in VO and OV further confirms that the information structure of OV has a special status for minimizers. $\mathrm{OV}$ can ensure that 'one'-phrases under negation are understood as minimizers, while there is an additional element in VO to make 'one'-phrases unambiguous.

\subsection{Occurrence of scalar particles, 也 yě and 都 dōu, in OV}

In Modern Mandarin OV, the type of focus which can induce scalar inferences becomes overtly specified as the 'one'-phrases as minimizers in OV are accompanied by the scalar particles, 也 yě and 都 döu. The two scalar particles are closely related to minimizers although their semantics differ greatly in other functions.

Specifically, 也 yě is treated as a focus-sensitive additive particle (cf. too, also) and as focus-sensitive scalar particle (cf. even) (Kobuchi-Philip 2009; Szabolcsi et al. 2014). 都 dōu, on the other hand, can serve as a focus-sensitive scalar particle,

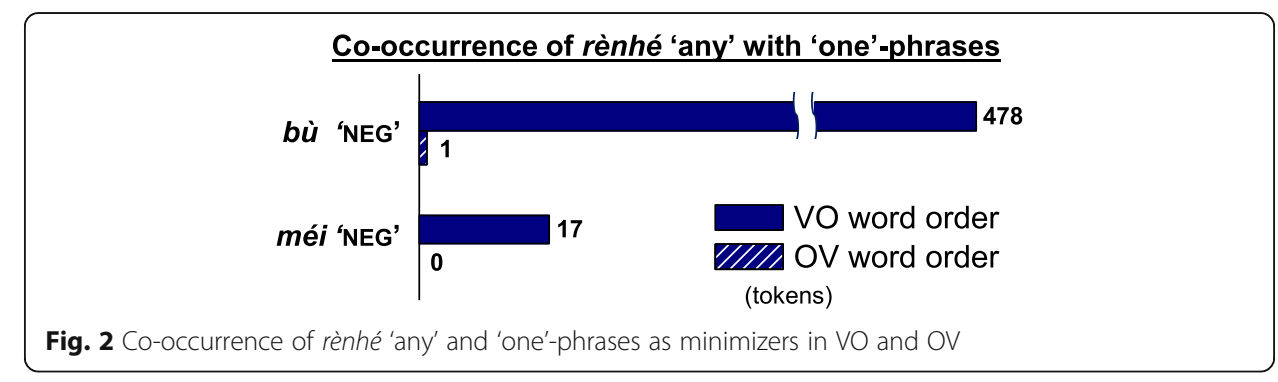


a universal quantifier, and a distributive operator in modern Chinese (Szabolcsi et al. 2014). Although each of the two groups of particles covers a different range of functions, they are both understood as focus-sensitive scalar particles when attached to those 'one'-phrases expressing a minimal amount. In the environment where both negation and minimizers co-occur, the particles amount to the equivalent of not even in English. The involvement of scalar particles is the result of creating maximal distinction between various types of focus carried in OV. The scalar particles emerged in OV around Early Mandarin, but they were not required at the time. However, in Modern Mandarin the great majority of the 'one'-phrases as minimizers in OV co-occur with the scalar particles, as shown in Fig. 3.

Although the 'one'-phrases which lack a scalar particle constitute a relatively small proportion, they form a distinct category for conveying a formal register. This class of minimizers is judged to be more archaic and may be viewed as vestiges from earlier periods of Chinese. The 'one'-phrases of this category have two properties. First, the majority of them are fixed expressions or idioms, as shown in (25) and (26). These two idiomatic expressions can be dated back to Old Chinese. They keep the syntactic characteristics of Old Chinese, where focus-sensitive particles were absent in OV.

(25）公私分明,一絲不苟 [Chinese Gigaword]

gōng_sì_fēn_míng,_[yì_sī]_bù_gǒu public_private_separate_clear_one_shred_NEG_mess up

...separate public and private interests, and not mess up even one shred [an idiom to meaning 'scrupulous']

(26）要能公正無私,一介不取 [Chinese Gigaword]

yào_néng_gōngzhèng_wú_sì,_[yí_jiè]_bù_qŭ

must_be-able-to_fair_NEG_private_one_seed_NEG_take

must be able to be impartial, and not take even one seed [an idiom meaning 'not

take anything not belonging to oneself']

Second, those without scalar particles tend to appear in parallel clauses, as shown in (27) and (28). The parallel clauses are pervasively used in slogans for stylistic formal symmetry. This type of 'one'-phrases also sounds archaic because they appear as though they are the vintages of archaic forms. The tendency of appearing in dependent clauses instead of independent clauses indicates that the form without a scalar particle is not a typical syntactic presentation of minimizers.

(27) 一趟不白走,一句不白問 [Chinese Gigaword]

$$
\text { [yí_tàng_bù_bái_zòu],_[yí_jù_bù_bái_wèn] }
$$

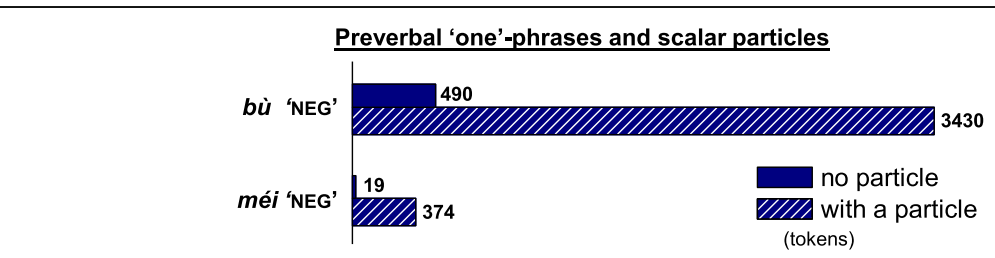

Fig. 3 Involvement of the scalar particles in OV containing 'one'-phrases as minimizers 
one_trip_NEG_in-vain_walk_one_sentence_NEG_in-vain_ask

not have even one trip for nothing and not ask even one sentence for nothing

(28) 安全一事不出,紀律一章不違 [Chinese Gigaword] ānquán_[yí_shì_bù_chū],_jilù__[yì_zhāng_bù_wéi] safe_one_thing_NEG_happen_discipline_one_chapter_NEG_violate With respect to safety, not a single accident happens. With respect to discipline, not a single rule is violated.

The preverbal 'one'-phrases without scalar particles thus have their own syntactic and pragmatic characteristics, departing from the canonical contemporary use.

As shown in Fig. 3, the majority of the preverbal minimizers occur with the scalar particles. As shown in (29) and (30), the occurrence of the particles overtly specifies scalar focus and reinforces the scalar nature of the associated 'one'-phrases.

(29) 倒!一瓶也不留 [Chinese Gigaword]

dào!_[yì_píng]__yè_bù_liú

pour-out_one_bottle_FOC_NEG_keep

Pour (them) out! Don't keep even a single bottle.

（30）家裡的牛羊一隻都沒損失 [Chinese Gigaword]

jiâlǐ̀de_niú_yáng_[yì_zhī]_dōu_méi_sǔnshī

in-the-house_cow_sheep_one_CLF_FOC_NEG_lose

...did not lose even a single cow or sheep

In brief, the 'one'-phrases as minimizers in OV are highly profiled. Moreover, the occurrence of focus-sensitive scalar particles enhances the scalar inferences from minimizers. These factors explain why minimizers favor OV: minimizers tend to occur in the positions where they are maximally profiled due to their emphatic nature.

\subsection{Double-object construction}

Although OV better accommodates minimizers in several ways, some minimizers still have to appear in VO rather than in OV. This is partly due to the syntactic constraints of Mandarin double-object construction as it is VO instead of OV that allows the double-object construction. As shown in (31) and (32), the double-object construction involves the form, $\mathrm{V} \mathrm{Obj_{1 }}$ $\mathrm{Obj}_{2}$, where the 'one'-phrase in the position of $\mathrm{Obj}_{2}$ is the direct object of the verb. The focal stress of the two examples falls on the 'one'-phrase, indicating that the 'one'-phrase is employed as an emphatic NPI. In contrast, OV takes only one object argument, as shown earlier in (29) and (30). There is no case that an "indirect" object is instantiated in OV.

（31）沒喝我們一口水,卻像親兄弟一樣關心 [Chinese Gigaword] méi_hē_wǒmen 1 _[yì_kǒu_shuǐ $]_{2}$ què__xiàng_

qīn_xiōngdì_yíyàng_guānxīn

NEG_drink_us_one_MW_water_but_alike_close_

brother_same_care-about

(He) did not drink a mouthful of our water, but treated us like his close brothers 
（32）大家苦幹五年,沒要國家一分錢 [Chinese Gigaword]

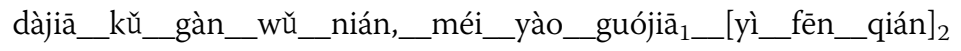

everyone_hard_work_five_year_NEG_ask-

for_country_one_cent_money

Everyone worked hard for five years and did not ask the country for a cent.

In sum, $\mathrm{VO}$ is relatively flexible to be combined with a variety of constructions, such as a double-object construction. The flexibility offers an explanation as to why there is still a fair portion of minimizers in VO.

The discussion of this section reveals that minimizers tend to occur in OV under non-existential negation. Their distribution reflects both the characteristics and constraints of the information structure of OV. On the other hand, the 'one'-phrases as minimizers under existential negation have different kinds of distributional constraints, which will be discussed in Section 4.

\section{4 'One'-phrases as minimizers with existential negation}

When 'one'-phrases appear with the existential negative predicate of 沒有 méiyǒu, the 'one'-phrases as minimizers do not show a tendency toward OV. Indeed, in the context of 沒有 méiyǒu, the majority of 'one'-phrases as minimizers, up to 13,650 tokens, appear in VO, while fewer than 3000 tokens are found in OV. The vast difference suggests that existential negation has a remarkable influence on the distribution of 'one'-phrases as minimizers in the two word order patterns. The distribution implies that Mandarin existential constructions should be able to provide the required informative conditions in semantics and pragmatics for 'one'-phrases to be interpreted as minimizers. In addition, the existential construction in $\mathrm{VO}$ is compatible with a variety of syntactic construals which cannot be accommodated by OV. Due to the syntactic characteristics, the VO with existential negation has a big portion of minimizers.

As regards syntactic structures, the Mandarin Chinese existential negator 沒有 méiyǒu verb can appear as the sole predicate of the sentence, as shown in (33). It is often preceded by a locative NP. The locative NP in (34), for instance, clearly defines the location where the existence of passengers is concerned.

（33）但是迄今還沒有一點跡象 [Chinese Gigaword]

dànshì_qì_jīn_hái_méiyǒu_[yì_diǎn_jīxiàng]

but_till_now_still_NEG.EXT_one_dot_sign

but till now there is still no sign...

（34）雖然機上沒有一位乘客,但這架飛機... [Chinese Gigaword]

suīrán_jī_shàng_méiyǒu_[yí_wèi_chéngkè,_dàn_zhè_jià_fēijī

although_flight_on_NEG.EXT_one_CLF_passenger_but_this_CLF_flight

Although there is not one single passenger on board, the flight...

The constraints of Mandarin existential constructions on the distribution of minimizers are exemplified by the cases where 'one'-phrases as minimizers have modification, either predicative clauses or relative clauses. In addition, the requirement of focal prominence of minimizers is reflected in the preferred unit of a 'one'-phrase. 


\subsection{Modification in VO: post-NP predicative clauses}

Mandarin Chinese existential sentences allow a more complicated structure, where the existential NP is followed by a predicative clause, as shown in (35) and (36). The subtype of existential presentative sentences has a discourse function to present an NP to be further described (Huang 1987; Li and Thompson 1981). As in (35), the NP 'one person' is an indefinite referential expression with the detailed action provided by a predicative clause. The indefinite numeral phrase 'one tree' in (36) is provided with more details by its following adjectival predicate.

(35) 外面有一個人敲門

wàimiàn_yǒu_[yí_ge_rén]_qiāo_mén

outside_EXT.V_one_CLF_person_knock_door

There is someone outside knocking on the door.

(36) 院子裡有一棵樹很高

yuànzi_lǐ_yǒu_[ỳ̀_kē_shù]_hěn_gāo

court-yard_in_EXT.V_one_CLF_tree_very_high

There is a tree in the yard which is very tall.

The same structure also applies to existential negation 沒有 méiyǒu. For instance, the 'one'-phrase introduced by 沒有 méiyóu in (37) is followed by a verb phrase which provides relevant details. In (38), the whole VP following the 'one'-phrase functions as a restrictive clause specifying the property concerned in the discussion. Similarly in (39), the idiomatic expression yì fán fêng shùn with its literal meaning of 'having favorable winds for sailing' is used to describe a process going smoothly.

（37）沒有一個患者的檢驗結果呈陽性 [Chinese Gigaword]

méiyǒu_[yí_ge_huànzhě_de_jiǎnyàn_jiéguǒ]_chéng_yángxìng

EXT.V_one_CLF_patient_POSS_inspection_result_show_positive

No patient has positive results

（38）將來沒有一個國家能保護它的環境 [Chinese Gigaword]

jiānglái_méiyǒu_[yí_ge_guójiā]_néng_bǎohù_tā_de_huánjìng

future_EXT.V_one_CLF_country_can_protect_3.SG_POSS_environment

There will be no country that can protect its environment in the future.

（39）沒有一件事一帆風順 [Chinese Gigaword]

méiyǒu_[yí_jiàn_shì]_ỳ̀_fán_fēng_shùn

EXT.V_one_CLF_thing_one_sail_wind_smooth

There is not a thing which goes smoothly without a hitch.

Based on the corpus data, the majority of 'one'-phrases as minimizers with existential negation 沒有 méiyǒu are followed by a phrase of predication, as exemplified in (37)-(39). This type of "complicated" existential construction involving more than one predicate only appears in VO. The preverbal object in OV, on the contrary, allows no predicative phrases. 
If there is any modification for the preverbal 'one'-phrase, it has to precede the noun of the 'one'-phrase. In (40), for example, the adjective occurs between the classifier and the noun.

（40）連一位中國留學生都沒有 [Chinese Gigaword]

lián_[yí_wèi_zhōngguó_liúxuéshēng]_dōu_méiyǒu

even_one_CLF_Chinese_overseas-student_FOC_EXT.NEG

There is not even a single Chinese overseas student.

This contrast shows that minimizers in VO and OV favor different strategies of modification. The next section will discuss the preferred modification for minimizers in OV.

\subsection{Modification in OV: relative clauses}

Examples (41) and (42) illustrate the different requirements regarding modification in $\mathrm{VO}$ and OV. Modification for 'one'-phrases as minimizers tends to appear as predicative clauses in VO, while modification for 'one'-phrases in $\mathrm{OV}$ is in the form of relative clauses. Predicative clauses have to immediately follow 'one'-phrases, whereas relative clauses with the relative marker de precede 'one'-phrases. In (41), the 'one'-phrase in VO is followed by a predicative clause in boldface. If it is paraphrased using OV, the phrase of predication has to be expressed by a relative clause, as in (42).

(41) 尤其是聯合國,沒有一個會員國可以代表台灣 [Chinese Gigaword] yóuqí_shì_liánhéguó,_méiyǒu_[yí_ge_huìyuán_guó] specifically_FOC_United-Nations_EXT.NEG_one_CLF_member_country kěyì_dàibiǎo_táiwān can_represent_Taiwan Specifically in the United Nations, there is no member country that can represent Taiwan.

（42）尤其是聯合國,一個可以代表台灣的會員國也/都沒有 yóuqí_shì_liánhéguó,_[yí_ge_kěyì_dàibiǎo_táiwān_de_ specifically_FOC_United-Nations_one_CLF_can_represent_

\section{Taiwan_REL} huìyuán_guó]_yě/dōu_méiyǒu member_country_YE/DOU_EXT.NEG Specifically in the United Nations, there is not even a single member that can represent Taiwan.

Relative clauses associated with numeral phrases may appear in two positions: (a) the position between the unit word and the noun and (b) the position preceding the numeral (Huang et al. 2009). However, relative clauses in the two positions convey different meanings. The relative clauses in position (a) are "non-restrictive," whereas those in position (b) are "restrictive" (Chao 1968; Hashimoto 1971; Huang et al. 2009). ${ }^{6}$ Regarding the 'one'-phrases used as minimizers, relative clauses tend to appear in position (a), as shown in (42). Relative clauses appearing in position 
(b) of numeral phrases may be judged to be unnatural, as shown in (43). The awkwardness has to do with the fact that the relative clause in this position makes the 'one'-phrase specific or definite. Since minimizer NPIs must be non-specific indefinites, relative clauses in position (b) are less preferred and hence not found in OV in the corpus.

（43）??尤其是聯合國,可以代表台灣的一個會員國也/都沒有

??yóuqí_shì_liánhéguó,_kěyì_dàibiǎo_táiwān_de_

specifically_FOC_United-Nations_can_represent_Taiwan_REL_

[yí_ge__hùyuán_guó]_yě/dōu_méiyǒu

one_CLF_member_country_FOC/FOC_EXT.NEG

Specifically in the United Nations, there is not even a single member country that can represent Taiwan.

Relative clauses can also modify 'one'-phrases as minimizers in VO, as shown in (44), which is paraphrased from (41). However, in some cases, the strategy of modification is not ideal in VO. For example, if (38) is paraphrased with a relative clause in VO, the grammatical acceptability becomes problematic, as in (45), which is even rejected by some native speakers. The ungrammaticality of (46) further confirms that position (b) is less ideal for relative clauses to modify minimizers. In VO, relative clauses have some constraints, as shown in the awkwardness resulting from the co-referential constraints between the pronoun and 'country'.

（44）尤其是聯合國,沒有一個可以代表台灣的會員國

yóuqí_shì_liánhéguó,_méiyǒu_[yí_ge_kěyì_

specifically_FOC_United-Nations_EXT.NEG_one_CLF_can_

dàibiǎo_táiwān__de_huìyuán_guó]

represent_Taiwan__REL_member_country

Specifically in the United Nations, there is not a member country that can

represent Taiwan.

（45）??將來沒有一個能保護它的環境的國家

??jiānglái__méiyǒu_[yí_ge_néng_bb̌ohù_tā_de_huánjìng_de_guójiāa

future_EXT.NEG_one_CLF_can_protect_3.SG_POSS_environment_

REL_country

There will not be a country that can protect its environment in the future.

（46）＂將來沒有能保護它的環境的一個國家

"jiānglái_méiyǒu_[néng_băohù_tā_de_huánjìng_de_yí_ge_guójiā]

future_EXT.NEG_can_protect_3.SG_POSS_environment_REL_

one_CLF_country

Intended reading: There will not be a country that can protect its environment in the future.

The preference of a predicative clause over a relative clause in VO can be observed in the corpus data, where up to $95 \%$ of the 'one'-phrases as minimizers in VO are 
followed by a predicative clause, but relative clauses for modification are relatively unproductive. The skewed distribution mainly attributes to two reasons. One is due to the syntactic constraints of relative clauses and predictive clauses. For example, predictive clauses better accommodate the involvement of co-referential relations than relative clauses do, as shown in (38), (45), and (46). In the corpus data of the minimizers, no tokens involving co-referenciality are found in the relative clauses. Since predictive clauses have relatively less constraints, the modification via predictive clauses is more productive. The other is the saliency of focal prominence. The existential constructions profile the NP introduced by the existential verbs, and hence this profiled numeral phrase is foregrounded with focal stress. As in (47), the 'one'-phrase is stressed. The intervention of a long relative clause weakens the stress of the numeral phrase, resulting in the decrease of the emphatic effects, as in (48), the paraphrase of (47) with a relative clause. Based on eight native Mandarin speakers' judgments, they are both grammatical but (47) is preferred.

(47) 沒有一家銀行像花旗銀行一樣 [Chinese Gigaword]

méiyǒu_[yí_jiā_yínháng]_xiàng_huāqíyínháng_yíyàng

EXT.NEG_one_CLF_bank_be-like_Citi-bank_same

There is no bank that is like Citi bank.

（48）沒有一家像花旗銀行一樣的銀行

méiyǒu_[yí_jiā_xiàng_huāqíyínháng_yíyàng_de_yínháng]

EXT.NEG_one_CLF_be-like_Citi-bank_same_REL_bank

There is no bank that is like Citi bank.

Relative clauses are rarely found in VO and also seldom appear to modify 'one'phrases as minimizers in OV with existential negation. In fact, 'one'-phrases tend to remain as a basic unitin OV. As shown in (49)-(51), the 'one'-phrases normally do not have additional modification as the information relevant to the 'one'-phrases is normally supplied from earlier contexts. For example, the numeral 'one'-classifier combination in (50) is associated with the 'tent' in the previous clause. In a similar vein, the relevant information about the 'one'-phrase in (51) is specified in its preceding clause. The classifier alone is sufficient to delimit the basic unit of its associated noun, so the noun which appears earlier in the context is free from repetition. Notably, in the corpus, up to $98 \%$ of the 'one'-phrases as minimizers in OV appear in the form of 'one'classifier/measure word immediately preceding the scalar particle as in (50) and (51). The high percentage indicates that there is a preferred size to be in focus. Since the preverbal object of the OV construction has focal prominence, the object with a focus stress tends to be a small unit in order to increase the saliency of prosodic prominence. As a result, the basic component of 'one'-phrases without additional modification enhances the semantic prominence of the minimizer by narrowing the focus site to the 'one'-phrase only.

（49）他如果坐在家裡,一票也沒有 [Chinese Gigaword]

tā_rúguǒ_zuò_zài_jiā_lǐ,_[yí_piào]_yě_méiyǒu

he_if_sit_at_home_in_one_vote_YE_NEG.EXT 
If he sits at home, there will not be even a single vote (for him).

(50) 要申領五百頂帳篷,一頂也沒有 [Chinese Gigaword]

yào_shēnlǐng_wǔ_bǎi_dǐng_zhàngpéng,_[yì_dǐng]_yě_méiyǒu

have-to_apply-for_five_hundred_CLF_tent,_one_CLF_FOC_NEG.EXT

...plan to apply for five hundred tents, but there is not even a single one.

(51) 有機會拿金牌的項目,幾乎一個也沒有 [Chinese Gigaword]

yǒu_jīhuì_ná_jīnpái_de_xiàngmù,_jīhū__yí_ge]_yě_méiyǒu

have_chance_get_gold-medal_REL_item_almost_one_CLF_

FOC_NEG.EXT

There is almost not a single category in which there is a chance to win a gold medal.

Based on the data, the preverbal 'one'-phrases as minimizers are generally not newly introduced information in the discourse. As shown in (52), the first clause clearly conveys a negative proposition, but the preverbal 'one'-phrase in the second clause repeats the information for the sake of emphasis and reinforcement.

（52）沒有人下去,一個也沒有 [Chinese Gigaword]

méiyǒu_rén_xià_qù,_[yí_ge]_yě_méiyǒu

NEG.EXT_person_down_go_one_CLF_FOC_NEG.EXT

Nobody went down, not even a single one.

The different constraints on the modification for minimizers associate with the strategies for maximizing pragmatic effects. Thus, the distribution of minimizers is linked to how arguments are profiled under different syntactic constraints.

\subsection{Emphatic effects behind preferred modifying strategies}

The discussion so far concerns how the information structure of $\mathrm{OV}$ and $\mathrm{VO}$ is reflected in the syntactic constraints of the 沒有 méiyou existential construction. The differences of modification in $\mathrm{VO}$ and $\mathrm{OV}$ are summarized in (53).

(53) 'One'-phrases as minimizers in the existential construction

\begin{tabular}{lll}
\hline & VO word order & OV word order \\
\hline 'one'-phrase followed by another expression of predication & $\sqrt{ }$ & $x$ \\
'one'-phrase modified by a relative clause & $\sqrt{ }$ & $\sqrt{ }$ \\
\hline
\end{tabular}

In $\mathrm{VO}$, although both predicative clauses and relative clauses can be used to provide further information for 'one'-phrases, the strategy of using predicative clauses is preferred. The preference is relevant to the issue of placing the minimizer in prosodic saliency. Due to the syntactic constraints in OV, predicative phrases cannot be accommodated. Because of the restriction, there is still a great amount of 'one'-phrases as minimizers in $\mathrm{VO}$ although $\mathrm{OV}$ is relatively ideal for minimizers. Even though the three strategies of providing further information of the 'one'-phrases are all legitimate, the actual use in the corpus shows that the choice of the form for modification is 
determined by the principle of maximally profiling the focused elements. Particularly in $\mathrm{OV}$, the 'one'-phrases have the tendency to remain as a basic numeral phrase without extra modifiers and even appear in the form which omits the noun. Remaining as a basic unit contributes to foregrounding the 'one'-phrases as minimizers both phonologically and semantically. The preference of a specific form of 'one'-phrases in the corpus is for inducing the strongest emphatic effects. In brief, the synchronic distribution of 'one'-phrases in $\mathrm{VO}$ and $\mathrm{OV}$ under different types of negation is the result of weighing syntactic, semantic, pragmatic, and discourse-level properties with the purpose of achieving the best condition for foregrounding minimizers.

\section{Diachronic influences on synchronic distribution}

Previous sections show that the distribution of minimizers in $\mathrm{VO}$ and $\mathrm{OV}$ is constrained by various synchronic constraints including negation, focus, and existential structures. In addition to these factors, diachronic factors also contribute to the distribution.

\subsection{Two types of minimizers in VO and OV}

Mandarin 'one'-phrases can be divided into two major types, non-fixed and fixed 'one'phrases, based on the relationship between the measure words/classifiers and the NPs associated with them. The two types are distinguished based on whether the UW slot between - yi 'one' and the NP can be freely occupied by different unit words, including various classifiers and measure words. The fixed type allows only 點 diăn 'dot' in the UW position, whereas the non-fixed type can accommodate different UWS. The sequences of the two types of 'one'-phrases are shown in (54). Based on the Academia Sinica Ancient Chinese Corpus, the fixed 'one'-phrases are later developments than the non-fixed ones, and they are both highly productive in Modern Mandarin.

(54) a. non-fixed 'one'-phrase: $y \bar{l}$ 'one'-UW-noun

b. fixed 'one'-phrase: yì 'one'- 點 diăn 'dot'-noun

The distribution of fixed 'one'-phrases in Modern Mandarin provides more evidence to reveal the tight connection between pragmatic effects and the employment of syntactic constructions.

Non-fixed and fixed 'one'-phrases have different degrees of sensitivity toward negative polarity. Non-fixed 'one'-phrases under negation in $\mathrm{VO}$ are not exclusively minimizers, as discussed in Section 3. However, when fixed 'one'-phrases appear under negation in VO, they must be understood as minimizers are shown in (55) and (56). Fixed 'one'-phrases can designate a dot-shape smallest unit, as in (55), where the shape of a water splash is specified. However, they are frequently used to refer to the smallest quantity of the referents which lack a concrete shape, as in (56). According to the data, the fixed 'one'-phrases in VO all include their basic three components: the numeral 'one', the unit word diăn 'dot', and a noun.

（55）沒淺起一點水花 [Chinese Gigaword]

méi_jiàn_qì_[yì_diăn_shuǐhuā]

NEG_splash_up_one_dot_sprinkle 
...did not splash a bit.

（56）不冒一點風險 [Chinese Gigaword]

bú_mào_[ỳ̀_diăn_fēngxiăn]

NEG_adventure_one_dot_risk

...does not take any risk.

When Modern Mandarin 'one'-phrases as minimizers are grouped by the division of fixed and non-fixed 'one'-phrases, it can be observed that the majority of 'one'-phrases as minimizers in VO belong to the non-fixed type, as shown in Fig. 4.

In contrast, the proportion of 'one'-phrases regarding the fixed and non-fixed division in OV with the scalar particle YE or DOU is reversed. The fixed 'one'-phrases constitute the majority of the tokens of 'one'-phrases as minimizers in the preverbal object position, as shown in Fig. 5.

The distribution is associated with the difference in terms of the degrees of behaving as a novel construction. Fixed 'one'-phrases have undergone changes in semantics, morphology, and collocation, so that they have different features from those of numeral phrases. The process of constructionalization, which refers to the process of creating novel constructions (Traugott 2008; Traugott and Trousdale 2013), will be discussed in Section 5.2. The diachronic factors provide further evidence on the relation between pragmatic effects and syntactic construals, which will be discussed in Section 5.3.

\subsection{Constructional differences of the two types of minimizers}

The emphatic nature of minimizers is present in their preferred syntactic construals. In OV, the NUM-UW combinations of the two types of minimizers tend to stay adjacent to the scalar particle in order to increase saliency. Despite the fact that the two types of 'one'-phrases behave alike in OV, the two categories differ greatly regarding the degree of constructionalization. The NUM-UW combination of non-fixed 'one'-phrases still maintains its nominal property as a numeral phrase. Since it belongs to the nominal category, it is treated as a grammatical object in OV. For instance, sentence (57) can be paraphrased in VO, as shown in (58) and (59). The non-fixed 'one'-phrases in (58) and (59) are the grammatical objects of the predicate. This fact shows that the NUM-UW part of non-fixed 'one'-phrases adheres to the subcategorization of the predicate, so the syntactic and semantic relations to the predicate remain unchanged.

（57）台北員工一個也沒裁 [Chinese Gigaword]

táiběi_yuángōng__yí_ge]_yě_méi_cái

Taipei_employee_one_CLF_FOC_NEG_fire

Not a single employee is fired in Taipei.

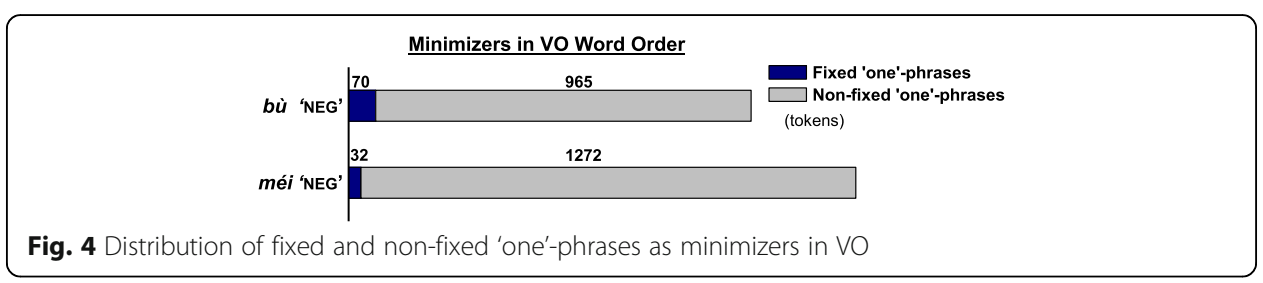




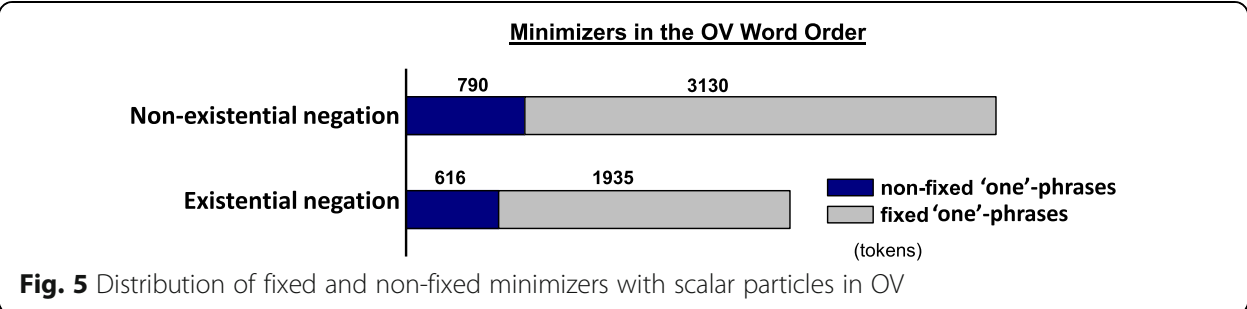

（58）沒裁一個台北員工

méi_cái_[yí_ge_táiběi_yuángōng]

NEG_fire_one_CLF_Taipei_employee

Not a single employee in Taipei is fired.

（59）台北員工沒裁一個

táiběi_yuángōng_méi_cái_[yí_ge]

Taipei_employee_NEG_fire_one_CLF

Not a single employee is fired in Taipei.

In contrast, the NUM-UW combination yì diă $n$ 'one dot' cannot function as the postverbal object in most cases, as reflected in the ungrammaticality of (60) and (61). This suggests that the NUM-UW combination of the fixed 'one'-phrase is not the object of the predicate.

(60) *他不相信一點

$$
\text { "tā_bù_xiāngxìn_[yì_diăn] }
$$

Intended reading: He does not believe even a little bit.

（61）商場沒察覺一點

"shāngchăng_méi_chájué_[yì_diǎn]

commercial center_NEG_realize_one_dot

Intended reading: The commercial center did not even realize a little bit.

In $\mathrm{OV}$, it is noteworthy that although the combination yì diăn 'one dot' seems to occupy the grammatical object position in OV, it is not part of the argument structure of the predicate. For instance, the main verbs 'shrink' in (62) and 'regret' in (63) are intransitive in Mandarin Chinese and therefore do not take an object argument. In these cases, the phrase yì diăn 'one dot' functions as an adverbial modifier of extent or degree for its following verb phrase. What makes the adverbial phrase seem to be a preverbal object is the occurrence of the scalar particles, DOU and YE, which can serve as an indicator of the OV construction. The similarity of the nominal and adverbial $y \grave{i}$ diăn indicates their diachronic connection.

（62）數量及種類一點也沒縮水 [Chinese Gigaword] shùliàng_jí_zhǒnglèi_[yì_diăn]_yě_méi_suōshuǐ 
quantity_and_kind_one__dot_FOC_NEG_shrink

The quantity and kinds do not shrink even a little bit.

（63）他哥哥一點都不後悔 [Chinese Gigaword]

tā_gēge_[yì_diǎn]_dōu_bú_hòuhuǐ

he_brother_one_dot_FOC_NEG_regret

His brother does not regret even a little bit.

The modifying function of yì diăn 'one dot' can also be observed in the clause where the verb is transitive and its argument structure is fully satisfied. As shown in (64)-(65), the transitive verbs 'have' in (64) and 'cherish' in (65) have their object immediately following them. Although the phrase yì diăn 'one dot' looks as if it occupies the position of the preverbal object, it is not the argument selected by the verb.

（64）對當時的情景一點也沒有印象 [Chinese Gigaword]

duì_dāngshíde_qíngjǐng_[yì_diǎn]_yě_méi_yǒu_yìnxiàng

to_then_scene_one_dot_FOC_NEG_have_impression

(He) does not have even a little bit of memory of the scene of the incident.

（65）似乎一點也不珍惜這種成就 [Chinese Gigaword]

sìhū_[yì_diăn]_yè_bù_zhēnxí_zhè_zhǒng_chéngjiù

seem_one_dot_FOC_NEG_cherish_this_kind_achievement

(He) seems not to cherish even a little bit of this kind of achievement.

Example (64) can be paraphrased with yì diăn 'one dot' as part of a nominal phrase as in (66). In this case, the whole nominal phase in the bracket in (66) should allow the alternation between VO and OV. As shown in (67), the same phrase is allowed in the postverbal position. The contrast between (64) and the pair of (66) and (67) shows that yì diăn 'one dot' in (64) syntactically differs from that in (66) and (67).

（66）對當時的情景一點印象也沒有

duì_dāngshíde_qíngjìng__yì_diăn_yìnxiàng]_yě_méi_yǒu

to_then_scene_one_dot_impression_FOC_NEG_have

(He) does not have even a little bit of memory of the scene of the incident.

（67）對當時的情景沒有一點印象

duì_dāngshíde_qíngjǐng_méi_yǒu_[yì_diăn_yìnxiàng]

to_then_scene_NEG_have_one_dot_impression

(He) does not have a little bit of memory of the scene of the incident.

Similarly, the fact that yì diăn 'one dot' is not part of the nominal phrase can be supported by the paraphrase of (65) in (68). The ungrammaticality shows that yì diăn 'one dot' does not belong to the postverbal nominal phrase.

（68）＊似乎不珍惜一點這種成就

"sìhū_bù_zhēnxí_[yì_diăn]_zhè_zhǒng_chéngjiù 
seem_NEG_cherish_one_dot_this_kind_achievement

(He) seems not to cherish even a little bit of this kind of achievement.

The contrasts in alternations indicate that yì diăn 'one dot' in (64)-(65) actually modifies its following clause. The modifying function of the phrase yì diăn 'one dot' is clear if the clause contains an adjectival predicate. In (69)-(70), what follows the negator is an adjectival predicate, such as 'romantic', 'fresh', and 'unfamiliar'. In this case, the phrase yi diăn 'one dot' is undoubtedly not the object even though it seems as though it is in the preverbal object position.

（69）這件事他們一點都不浪漫 [Chinese Gigaword] zhè_jiàn_shì_tāmen__yì_diăn]_dōu_bú_làngmàn this_CLF_thing_they_one_dot_FOC_NEG_romantic

Regarding this matter, they are not romantic at all.

(70) 所以今天跳起探戈一點也不陌生 [Chinese Gigaword] suǒyǐ_jīntiān_tiào_qù_tàngē__ỳ̀_diăn]_yě_bú_mòshēng therefore_today_dance_up_Tango_one_dot_FOC_NEG_unfamiliar Therefore when he danced Tango today, it was not unfamiliar to him at all.

The discussion of the phrase yì diăn 'one dot' with DOU and YE so far shows that it deviates from the nominal category and instead functions as an adverbial modifier. This development has been shaped by the construction where it occurs. When the phrase yì diăn 'one dot' functions as an adverbial, it collocates with a scalar particle, DOU or YE, and a negator, as shown in (62)-(70). The combination of the NUM-UW phrase, a scalar particle, and a negator is similar to the form of the typical OV construction containing 'one'-phrases as minimizers, as illustrated in Fig. 6. The presentation of form and meaning pairing is adapted from Croft and Cruse (2004: 258). The NUM-UW combination yi diăn 'one dot' appears precisely in the object position of the OV construction despite the fact that yi diann 'one dot' may not be the true grammatical object.

Based on Fig. 5, there are more fixed 'one'-phrases as minimizers in OV than in VO in Modern Mandarin. The tendency is a reflection of the high frequency of fixed 'one'-phrases in the preverbal object position. When the class expansion occurred in the predicate

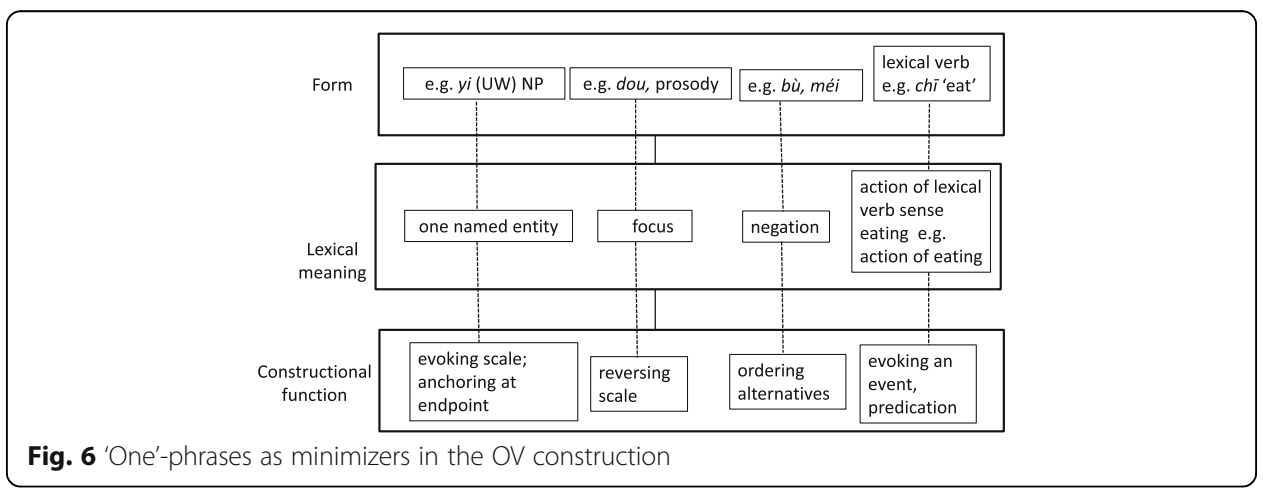


position of the construction, reanalysis of the construction was subsequently activated. The predicate gradually expanded from transitive verbs to intransitive verbs and even to adjectival predicates. Importantly, class expansion happened only in the cases where the fixed 'one'-phrases omit the noun, as exemplified in (62) and (63). If the noun remained in the fixed 'one'-phrases, its salient nominal property greatly reduced the chances of class expansion in the predicate. When the verb position is filled with predicates which do not belong to the category of transitive verbs, the relation between yi diăn 'one dot' and the predicate is reanalyzed as the relation between an adverbial modifier and its modified element. The adverbial-predicate relation emerged partly due to the syntactic and semantic similarities to the adverbial-predicate relation in Mandarin Chinese, wherein the adverbial modifiers generally precede their modified elements. As shown in (71), the adverb 根本 gēnběn 'simply' must precede the negator. It is noteworthy that 根本 gēnbèn 'simply' in (71) and 絲毫 sīháo 'shred and hair' in (72) are adverbial NPIs (Hsiao 2002). Unlike fixed 'one'-phrases as minimizers, they do not require a scalar particle.

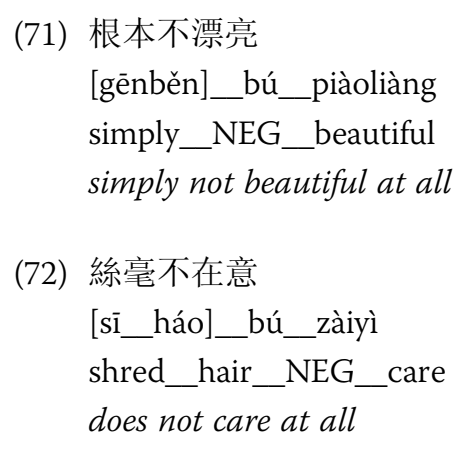

The adverbial function of yì diăn 'one dot' is absent in Old Chinese and Middle Chinese according to Academia Sinica Ancient Chinese Corpus. It can only be dated back to the period of Early Mandarin Chinese. Notably, the scalar particles DOU and YE must occur in the cases where yì diăn 'one dot' behaves as an adverbial modifier in the majority of cases, as shown in (62)-(65) and (69)-(70). The requirement of the scalar particle for fixed 'one'-phrases instead of other adverbial NPIs supports the hypothesis that the reanalysis has occurred in the OV construction. As illustrated in (73), the scalar particles are reminiscent of the OV construction. The scalar particle and yì diăn 'one dot' are generally viewed as a unit by native speakers due to their mandatory collocation. Their combination as a whole behaves as a strict NPI, which must appear with negation and cannot occur in other types of NPI-licensing environments.

Constructional changes are hypothesized to precede and enable constructionalization (Traugott and Trousdale 2013). The constructional changes before constructionalization typically involve expansion of pragmatics, semanticization, and distributional changes, as shown in the development of the nominal yì diăn 'one dot' toward an adverbial modifier. Such a combination with a negator has become a fixed expression, which can even be used as a short negative answer, as shown in (74). The whole phrase reinforces negation, which evokes strong scalar inferences than a bare negation does. 
(73)

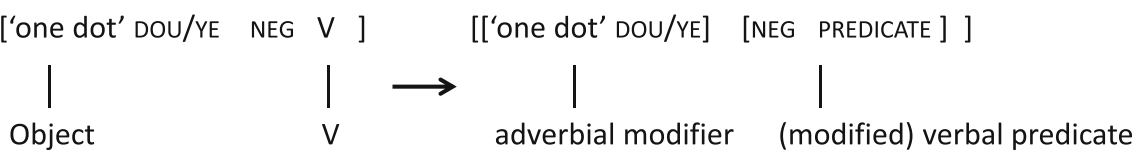

（74）訪美行程有爭議, 錢復說:「一點也沒有。」 [Chinese Gigaword] fang_měi_xíngchéng_yǒu_zhēngyì,_

visit_America_schedule_have_controversy_

qiánfù_shuō:_「yì_diǎn_yě_méiyǒu 。」

Qianfu_say_one_dot_FOC_NEG.EXT

The schedule of visiting America seems controversial. Qiánfü said: "Not at all."

This process reflects the principle that diachronic changes and grammaticalization do not occur only on a single lexeme, such as the numeral "one" or the unit word 'dot'. Instead, the construction changes as a whole. Specifically, the numeral-unit word combination yì diăn 'one dot' has been shaped by the construction where it frequently occurs. Its constructionalization also catalyzes other subsequent constructional changes, such as expansion of collocation. For example, the yì diăn 'one dot' phrase in Modern Mandarin can modify a wider variety of predicates. In this case, constructionalization and constructional changes provide environments for each other.

Not all 'one'-phrases as minimizers have undergone the same changes. These diachronic changes only occurred in the fixed 'one'-phrases, not in the non-fixed ones, even though both types appear in the same environments. The asymmetry has to do with the flexibility of replacing the unit word. The unit word diann 'dot' has formed a strong association with the concept of a small quantity. It can be used to refer to a minimal amount for various categories of nouns. In this sense, it is more general than typical individual classifiers and unit words. General classifiers tend to undergo constructionalization because they lack a distinctive image and thus are weaker in identifying an object. In other words, they are more likely to shift to the modifying function. In non-fixed 'one'-phrases, on the contrary, the numeral-classifier combination has maintained a salient nominal property because individual classifiers are inherently used to describe the gestalt characteristics of their associated nouns. Since the referencing function is strong, this function prevents the combination of the numeral 'one' and an individual classifier from shifting to another category.

The analysis so far shows that fixed 'one'-phrases advance farther on the path of constructionalization, and they have developed a stronger connection with the minimizer interpretation as shown in the discussed examples. With this property, their distribution provides convincing evidence for the association between focal prominence encoded in syntactic construals and pragmatic effects.

\subsection{The site of focus and the strength of pragmatic inferences}

Fixed 'one'-phrases serve as effective indicators for focal prominence due to their strong connection with negative polarity. The variation of their forms also associates with the importance of focal prominence in inducing scalar inferences. In OV, they 
appear in two forms. One is the canonical numeral phrase containing the three components: the numeral 'one', the unit word diăn 'dot'. and a noun, as shown in (75)-(76).

（75）對布希本人一點好處也沒有 [Chinese Gigaword]

duì_bùxī_běnrén_[yì_diăn_hǎochù]_yě_méiyǒu

to_Bush_personally_one_dot_advantage_FOC_NEG.EXT

There is not even a bit of advantage to Bush himself.

(76) 一點汗都流不出來 [Chinese Gigaword]

[yì_diăn_hàn]_dōu_liú_bù_chūlái

one_dot_sweat_FOC_flow_NEG_out

(He) did not sweat even a little bit.

The other form is the combination yi diăn 'one dot' without the noun. In OV, the combination yi diăn 'one dot' is more frequently found than the form composed of three elements. Indeed, yì diăn 'one dot' alone is often treated as a fixed unit, as shown in (77)-(78).

（77）購買世界杯相關產品的顧客一點也沒減少 [Chinese Gigaword]

gòumăi_shìièbēi_xiāngguān_chănpǐn_de_gùkè_[yì_diǎn]

purchase_World Cup_related_products_REL_customer_one_dot

yě_méi_jiǎnshǎo

FOC_NEG_diminish

The number of customers purchasing World Cup products does not diminish even a little bit.

（78）對中國的影響,不能說一點也沒有 [Chinese Gigaword]

duì_zhōngguó_de_yřngxiăng,_bù_néng_shuō_[yì_diăn]_yě_méiyǒu

to_China_REL_influence_NEG_can_say_one_dot_FOC_NEG.EXT

It cannot be said that it does not affect China at all.

The omission of the noun of the 'one'-phrase in OV is not found only in fixed 'one'phrases. As discussed in Section 4, non-fixed 'one'-phrases as minimizers tend to appear as the minimal size and omit the modifiers in order to maximize the prosodic and semantic prominence. The preference of one form over the other of 'one'-phrases is linked to the strategy for increasing focal effects.

Section 5 approaches the distribution of minimizers from a diachronic perspective. The type of fixed minimizers has a stronger tendency in OV than the other type of minimizers. In addition, they are more frequent in appearing as the smallest size. Due to their strong emphatic nature, their skewed distribution captures the different strengths of focal saliency of information structure in VO and OV.

\section{Conclusions}

This paper has discussed the synchronic distribution of 'one'-phrases as minimizers to investigate the information structure of a variety of constructions. Regarding word order, Modern Mandarin minimizers can occur in VO and OV, but they have an 
asymmetrical distribution under different types of negation. The corpus analysis shows that the distribution is constrained by the focal prominence required by the emphatic pragmatic effects of minimizers.

With their emphatic nature, Mandarin minimizers are reliable diagnostics for distinguishing the strengths of focus in various construals. The analysis shows that the minimizers favor OV under non-existential negation, while they prefer $\mathrm{VO}$ under existential negation. The asymmetrical distribution reflects how arguments are profiled in different word order patterns.

The study also provides a close examination on the strategies of modification, predicative clauses and relative clauses, for minimizers in different word order patterns. The comparison shows that the two clauses are not equally accommodated by $\mathrm{VO}$ and OV. Particularly, intervention between focus-sensitive scalar particles and minimizers in OV are not allowed. The constraint also explains why not all minimizers occur in the position with the strongest prominence. The involvement of modifiers leads to the discussion of the variation in the forms of minimizers. In OV, specifically, the 'one'phrases tend to occur as a concise unit with only the numeral and the unit word in order to maintain the prominent saliency in prosody and semantics.

The synchronic distribution has been shaped by diachronic development. Since one type of minimizers advanced farther on the way of constructionalization than the other, the comparison confirms the preferred positions and constructional sizes of minimizers. Thus, the diachronic development shows how pragmatic effects have been achieved overtime.

Minimizers relate the issues of negation, word order, focus, and scalarity. Their distribution offers an integrated perspective on how these elements interact. Through the investigation of their distribution, we can come to understand how the choice of syntactic construals is associated with pragmatic inferences.

\section{Endnotes}

${ }^{1}$ Following Zhang (2013), all types of CLFs and measure words are treated as unit words (UW). UW represents the ensemble of classifiers and measure words unless otherwise specified.

${ }^{2}$ Abbreviations: 3, third person; ASP, aspect; CLF, classifier; EXT., existential predicate; EXT.V, existential verb; FOC, focus; MW, measure word; NE, negation, negative; NUM, numeral; POSS, possessive; PTC, particle; REL, relative; SG, singular; UW, unit word

${ }^{3}$ Both bàn 'half' and $y \bar{l}$ 'one' can refer to a small quantity, and thus they are frequently employed as minimizers in Mandarin. As pointed out by a reviewer, 半 bàn 'half' can replace - yi 'one' in most cases of the minimizers.

${ }^{4}$ The Chinese Gigaword Corpus contains approximately 1.1 billion Chinese characters. The data come from two main sources. One is from Taiwan's Central News Agency (around 700 million characters), and the other is from China's Xinhua News Agency (around 400 million characters).

${ }^{5}$ The broader definition of the $\mathrm{VO} / \mathrm{OV}$ pattern is employed in order to show the generalization of positional variation constrained by Mandarin information structure. The existential sentences which have position IV do not allow the $\mathrm{VO} / \mathrm{OV}$ alternation as shown in (i) and (ii). 
(i) 桌上沒有一本小說有意思

I II III IV
zhuō_shàng_méi_yǒu_[yì_běn_xiăoshuō]_yǒuyìsi
table_top_NEG_EXT.V_one_CLF_novel_interesting

There are no interesting novels on the desk.

(ii) “桌上一本小說有意思都沒有

"zhuō_shàng_[yì_běn_xiăoshuō]_yǒuyisi_dōu_méi_yǒu

table_top_one_CLF_novel_interesting_FOC_NEG_EXT.V

Intended reading: There are no interesting novels on the desk.

A reviewer suggests that the contrast can be captured by the immovability of the small clause complement of méiyóu (Xie 2014). This study concerns how the syntactic constraint in modification of the existential sentences influences the distribution of minimizers in different word order patterns. The details will be discussed in Section 4.

${ }^{6}$ In the literature, there is no current consensus with respect to the analysis of Mandarin relative clauses. Del Gobbo and Francesca $(2003,2010)$ proposes an analysis against this restrictive versus non-restrictive (or descriptive/appositive) analysis. In her analysis, Mandarin relatives consistently behave as restrictive relative clauses. The restrictive versus descriptive contrast is analyzed as a deictic meaning versus generic meaning contrast (Del Gobbo and Francesca 2005). Although these analyses differ from each other, they all admit that relatives in different positions of the numeral phrases lead to different interpretations. In this section, I adopt Huang et al. (2009)'s distinction of two types of relatives to discuss how the position of relatives influences the acceptability of a minimizer interpretation. The principles are as follows: (i) relative clauses modify what follows them and (ii) the scope of modification is the elements to the right of the modifier. Relative clauses preceding numeral phrases modify the whole numeral phrase, while relative clauses appearing in the position between the unit word and the noun of a numeral phrase modify only the noun.

\section{Acknowledgements}

I would like to thank the editors and two anonymous reviewers for their insightful and constructive comments. My sincere gratitude is owed to the following people for their invaluable feedback and suggestions in this study: Eve Sweetser, Gary Holland, Peter Jenks, Chu-Ren Huang, and Rebecca Gross.

Competing interests

The authors declare that they have no competing interests.

\section{Publisher's Note}

Springer Nature remains neutral with regard to jurisdictional claims in published maps and institutional affiliations.

Received: 17 August 2016 Accepted: 4 August 2017

Published online: 30 September 2017

\section{References}

Allan, Keith. 1977. Classifiers. Language 53(2): 285-311.

Chao, Yuen-Ren. 1968. A grammar of spoken Chinese. Berkeley: University of California Press.

Cheng, Robert L. 鄭良偉. 1978. Tense interpretation of four Taiwanese modal verbs. In Proceedings of Symposium on Chinese Linguistics, 1977 Linguistic Institute of The Linguistic Society of America, ed. Robert L. Cheng, Ying-chi Li, and Ting-chi Tang 鄭良偉, 李英哲, 湯选池, 243-266. Taipei: Student Book Co. 
Giannakidou, Anastasia. 2011. Positive polarity items and negative polarity items: Variation, licensing, and compositionality. In Semantics: An international handbook of natural language meaning, ed. Claudia Maienborn, Klaus von Heusinger, and Paul Portner, 1660-1712. Berlin: Mouton de Gruyter.

Del Gobbo, Francesca. 2003. Appositives at the interface, Ph.D. dissertation. Irvine: University of California.

Del Gobbo, Francesca. 2005. Chinese relative clauses: Restrictive, descriptive or appositive? In Contributions to the XXX Incontro di Grammatica Generativa, ed. Laura Brugè, Giuliana Giusti, Nicola Munaro, Walter Schweikert, and Giuseppina Turano, 287-305. Venezia: Cafoscarina.

Del Gobbo, Francesca. 2010. On Chinese appositive relative clauses. Journal of East Asian Linguistics 19(4): 385-417.

Hashimoto, Anne Y. 1971. Mandarin syntactic structures. Unicorn 8: 1-149.

Haspelmath, Martine. 1997. Indefinite pronouns. Oxford/New York: Oxford University Press.

Horn, Laurence R. 1989. A natural history of negation. Chicago: The University of Chicago Press.

Hsiao, Su-ying. 2002. Negative sensitivity in Chinese: A comparative study of Mandarin Chinese and Holo Taiwanese. Ph.D. dissertation. Hsinchu, Taiwan: National Tsing Hua University.

Huang, C.-T. James. 1987. Existential sentences in Chinese and (in)definiteness. In The representation of (in)definiteness, ed. Eric J. Reuland and Alice G.B. ter Meulen, 226-253. Cambridge, MA: MIT Press.

Huang, C.-T., James, Audrey Y.-H. Li, and Yafei Li. 2009. Syntax of Chinese. Cambridge: Cambridge University Press.

Huang, Chu-Ren. 2009. Tagged Chinese gigaword version 2.0. Philadelphia: Linguistic Data Consortium, University of Pennsylvania.

Israel, Michael. 2011. The grammar of polarity: Pragmatics, sensitivity and the logic of scales. Cambridge: Cambridge University Press.

Kobuchi-Philip, Mana. 2009. Japanese MO: Universal, additive, and NPI. Journal of Cognitive Science 10: 172-194.

Li, Charles N., and Sandra A. Thompson. 1981. Mandarin Chinese: A functional reference grammar. Berkeley: University of California Press.

Peyraube, Alain. 1997a. On word order in archaic Chinese. Cahiers de Linguistique - Asie Orientale 26: 3-20.

Peyraube, Alain. 1997b. On word order and word order change in pre-archaic Chinese. Chinese Language and Linquistics 4: 105-124 Taipei: Institute of History and Philology, Academia Sinica.

Szabolcsi, Anna, James D. Whang, and Vera Zu. 2014. Quantifier words and their multi-functional(?) parts. Language and Linguistics 15(1): 115-155.

Traugott, Elizabeth C. 2008. Grammaticalization, constructions and the incremental development of language: Suggestions from the development of degree modifiers in English. In Variation, selection, development-probing the evolutionary model of language change, ed. Regine Eckardt, Gerhard Jäger, and Tonjes Veenstra, 219-250. Berlin/ New York: Mouton de Gruyter.

Traugott, Elizabeth C., and Graeme Trousdale. 2013. Constructionalization and constructional changes. Oxford: Oxford University Press.

Tsai, Wei-Tien D 蔡维天. 2004a. On formal semantics of zhi and lian in Chinese 谈“只"与“连”的形式语义. Chinese Language 中国语文 2: 99-111.

Tsai, Wei-Tien D 蔡维天. 2004b. On 'a person', 'some of the people', and 'some people' in Chinese 谈 "有人", "有的人" 和 "有些人". Chinese Linguistics 汉语学报 2: 16-25.

Xie, Zhiguo. 2014. The degree use of the possessive verb yǒu in Mandarin Chinese: A unified analysis and its theoretical implications. Journal of East Asian Linguistics 23(2): 113-156.

Zhang, Niina N. 2013. Classifier structures in Mandarin Chinese. Berlin: Mouton de Gruyter.

Zhang, Ning. 2000. Object shift in Mandarin Chinese. Journal of Chinese Linguistics 28(2): 201-246.

\section{Submit your manuscript to a SpringerOpen ${ }^{\circ}$ journal and benefit from:}

- Convenient online submission

- Rigorous peer review

- Open access: articles freely available online

- High visibility within the field

- Retaining the copyright to your article

Submit your next manuscript at $>$ springeropen.com 